\title{
Evaluation of Antimalaria Activity and Acute Toxicity of Xetospongia sp
}

\author{
${ }^{1}$ Syamsudin Abdillah, ${ }^{2}$ Rahmatul Wahida Ahmad, \\ ${ }^{3}$ Yatnita Parama Cita and ${ }^{2}$ Noriah Mohd Noor \\ ${ }^{1}$ Department of Pharmacology, Faculty of Pharmacy, \\ Pancasila University, Jl. Srengseng Sawah, Jagakarsa, South Jakarta 12640, Indonesia \\ ${ }^{2}$ Department of Biomedical Sciences, Kulliyah of Pharmacy, \\ International Islamic University Malaysia, Kuantan Campus, Malaysia \\ ${ }^{3}$ Department of Microbiology and Parasitology, School of Health Sciences, Istara Nusantara, Jakarta, Indonesia
}

Received 2013-08-20, Revised 2013-08-23; Accepted 2013-09-02

\begin{abstract}
We investigated the in vivo activity of extract of Xetospongia sp against Plasmodium berghei Strain ANKA and acute toxicity in mice. The ethanolic extracts of the Xetospongia sp (50-400 $\mathrm{mg} \mathrm{kg}^{-1}$ day) were screened for blood schizonticidal against $P$. berghei strain ANKA in mice during early and established infections. Acute toxicity of extracts of Xetospongia sp at the dose $5000 \mathrm{mg} \mathrm{kg}^{-1}$ on mice administeredorally exhibited no toxicity, as evident in that fact that no histopathological changes were observed in some essential organs, such as liver, heart, digestive tract and kidney. The ethanolic extracts $\left(50-400 \mathrm{mg} \mathrm{kg} \mathrm{day}^{-1}\right)$ exhibited a significant antimalarial activity both in the 4-day early infection test and in the established infection and they were found to be relatively safe up to a dosage of $5000 \mathrm{mg} \mathrm{kg}^{-1}$, with an $\mathrm{LD}_{50}$ value of $>500 \mathrm{mg} \mathrm{kg}^{-1}$.
\end{abstract}

Keywords: Xetospongia sp, Antimalarial Activity, Acute Toxicity

\section{INTRODUCTION}

Malaria is a disease of the tropics and subtropics. It is a global problem, endemic in 106 countries with an estimated 3.3 billion people at risk of malaria in 2010. In 2010 there were 216 million cases of malaria world wide, with an estimated 655,000 deaths WHO, 2011. In Indonesia, 1.25 to 2.5 million probable malaria cases with 45 to $50 \%$ being cases of Plasmodium falciparum, nearly 350,000 confirmed malaria cases and around 500 confirmed malaria deaths, are reported every year (SEARO, 2011).

The rise of antimalarial drug resistance has dominated global malaria control programs since resistance to chloroquine was first documented in patients in 1959. Chloroquine was the first widely used modern antimalarial, but within little more than a decade after its introduction Chloroquine Resistant (CQR) $P$. falciparum had emerged and begun to spread across
Asia. In areas of high grade CQR a new drug; Fansidar (Sulfadoxine-Pyrimethamine, SP) was adopted as the recommended therapy for uncomplicated falciparum malaria (Sibley and Price, 2012).

Drug resistance accompanied by lack of progress in the development of vaccines or resistant reversal agents has further aggravated the situation. Marine derived compounds have been explored and considered as possible anti-malarial agents. The marine sponge, Axinyssa djiferi, collected on mangrove tree roots in Senegal, was investigated for glycolipids have potent antimalarial activity (Farokhi et al., 2013). A new bispyrroloiminoquinone alkaloid, tsitsikammamine $\mathrm{C}$, from the Australian marine sponge Zyzzya sp displayed potent in vitro antimalarial activity and inhibited both ring and trophozoite stages of the malaria parasite life cycle (Davis et al., 2012).

One compound of sponge that has been found to have antimalaria activity is manzamine A. Manzamine A, a b-

Corresponding Author: Noriah Mohd Noor, Department of Biomedical Sciences, Kulliyah of Pharmacy, International Islamic University Malaysia, Kuantan Campus, Malaysia 
carboline alkaloid, was shown to inhibit the growth of the rodent malaria parasite Plasmodium berghei, not only in vitro but also in vivo (Ang et al., 2000). In the last two decades, the manzamine alkaloids have represented an important class of natural products for the development of new bioactive molecules for the treatment of malaria. Manzamin A alkaloids can be isolated from the sponge family Petrosiidae (Samoylenko et al., 2009).

Sponge from the genus of Petrosia commmonly found in Situbondo waters, East Java, Indonesia is Xetospongia sp (Abdillah et al., 2013). In vivo antimalaria test and acute toxicity test against Xetospongia sp were conducted as an effort to find bioactive compounds from natural ingredients, particularly sponge.

\section{MATERIALS AND METHODS}

\subsection{Animal Materials}

Sponge samples of Xetospongia sp was collected by scuba diving at a depth of about 8 and $500 \mathrm{~m}$ from the coastline in Tajung Pecaron Bay, near Situbondo, Indonesia. The selected sponge, Xetospongia sp. was well identified with the help of Laboratorium of Ecology of Marine, Department of Biology, Institute of Technologi Surabaya. A voucher specimen (No A24354) was deposited at Department of Biology, Faculty of Sciences, Institute Technology of Surabaya. The strain of $P$. berghei was provided by the Centre of Bioscience and Biotechnology, Faculty of Sciences and Technology, National University of Malaysia.

\subsection{Extract Preparation}

Freeze-dried or wet samples of the sponges were soaked twice in ethanol. Each soaking lasted for $24 \mathrm{~h}$. After filtration, the ethanol extracts were then evaporated under reduced pressure in a rotary evaporator and evaluated for their effectiveness against $P$. berghei parasites.

\subsection{Parasite Inoculation}

A single donor mouse infected with Plasmodium berghei parasites was blood into sterile heparinized culture medium and the blood was diluted with RPMI 1640 medium. The healthy experimental mice were infected intravenously via a tail vein with $0.2 \mathrm{~mL}$ of the diluted blood containing $1 \times 10^{7}$ parasitized (Plasmodium berghei) red blood cells on day one.

\subsection{Evaluation of Antimalarial Activity of the Extract of Xetospongia sp}

Evaluation of suppressive activity of the extract (4day test).
This test was used to evaluate the schizontocidal activity of the extract and chloroquine against early P.berghei infection in mice. This was done as described by Knight and Peters (1980) on the first day (Do), the seventy-two mice were infected with the parasite and randomly divided into various groups (n $=6$ ). These were administered with the extract and chloroquine. The mice in group 1 were administered with $400 \mathrm{mg} \mathrm{kg}^{-1}$, group 2, $200 \mathrm{mg} \mathrm{kg}^{-1}$, group 3, 100 $\mathrm{mg} \mathrm{kg}{ }^{-1}$, group $4,50 \mathrm{mg} \mathrm{kg}^{-1}$ of the crude extract, Chloroquine was given to the positive control group (group 5) and $10 \mathrm{~mL} \mathrm{~kg}^{-1}$ of distilled waterto negative control group (Group 6) for fourconsecutive days (D0D3) between $8 \mathrm{am}$ and 9am. On thefifth day (D4), thin blood film was made from tail blood.The film was then stained with Leishman's stain to reveal parasitized erythocytes out of 200 in a random field of themicroscope.

\subsection{Evaluation of Curative Activity (Rane's test)}

This was used to evaluate the schizontocidal activities ofthe extracts and chloroquine in established infection. Thiswas done as described by Ryley and Peters (1970). P.berghei was injected intraperitoneally into groups of mice $(n=6)$ on the first Day (Do). Seventytwo hours later (D3), the mice was divided randomly into groups of six mice each. Different doses of the leaf extract, 400, 200, 100 and $50 \mathrm{mg} \mathrm{kg}^{-1}$ were orally administered respectively to mice in groups $1-4$, the extract, $5 \mathrm{mg} \mathrm{kg} \mathrm{day}^{-1}$ of chloroquine (positive control) and $10 \mathrm{~mL} \mathrm{~kg}^{-1}$ of distilled water (negative control) were respectively given to mice in Groups 5 and 6 . The extract and drugs were administered once daily for5 days. Leishman's stained thin smears were prepared from tail blood samples collected on each day of treatment to monitor parasitaemia level. The Mean Survival Time (MST) of the mice in each treatment group was determined over a period of 29 days (D0-D28).

\subsection{Acute Toxicity Test}

The acute toxicity of extracts weretested on rats using 3 doses $\left(625,2500\right.$ and $5000 \mathrm{mg} \mathrm{kg}{ }^{-1}$ body weight) administered orally. Control rats were kept under the same conditions without any treatments. The animals were routinely inspected for appearances or signs of toxicity such as tremors, weakness and refusal of feeds, falling off hair, coma or even death for $48 \mathrm{~h}$. The Lethal Dose $\mathrm{LD}_{50}$ was estimated from the graph of percentage mortality converted to probit against log-dose of the extract, probit 5 being $50 \%$. 


\section{RESULTS}

\subsection{Evaluation of Suppressive Activity of the Extract ( 4-Day Test)}

On the day 5, extract of Xetospongia sp yielded \%suppression of $60,23 \%$ for a dosage of $400 \mathrm{mg} \mathrm{kg}$ day $^{-1}, 42,48 \%$ for a dosage of $200 \mathrm{mg} \mathrm{kg} \mathrm{day}{ }^{-1}, 25,91 \%$ for a dosage of $100 \mathrm{mg} \mathrm{kg} \mathrm{day}^{-1}$ and $3,86 \%$ for a dosage of $50 / \mathrm{kg} /$ day. Based on these findings, treatment groups receiving extracts at a dosage of $400 \mathrm{mg} \mathrm{kg}$ day $^{-1}$ exhibited a lower parasitemia rate than any other treatment groups even though it was still lower than that of positive control group (chloroquine treatment group).

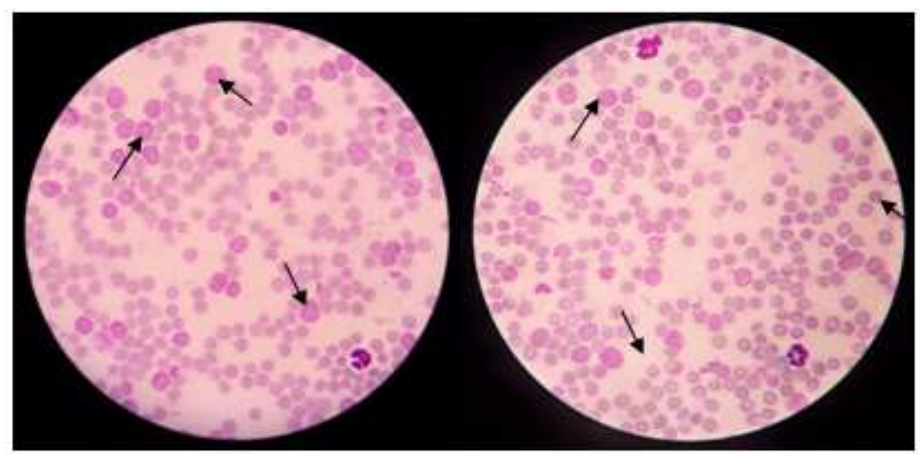

Extract dosage of $50 \mathrm{mg} \mathrm{kg} \mathrm{day}^{-1} \quad$ Extract dosage of $100 \mathrm{mg} \mathrm{kg} \mathrm{day}^{-1}$

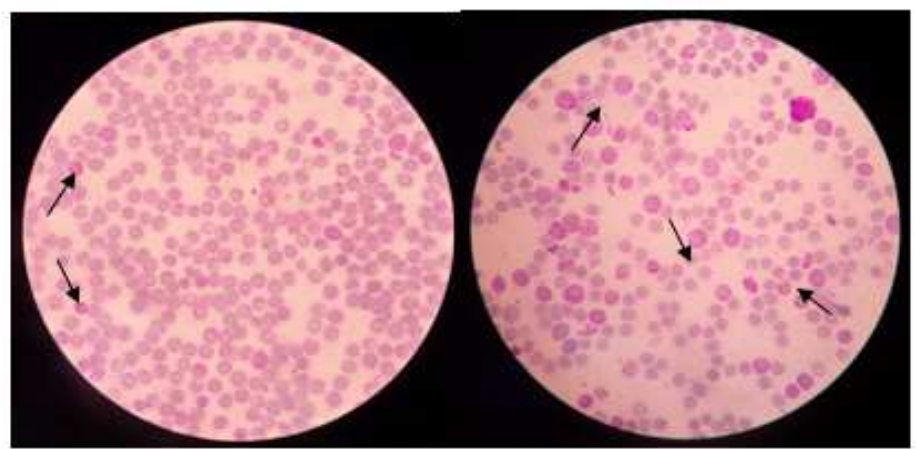

Extract dosage of $400 \mathrm{mg} \mathrm{kg} \mathrm{day}^{-1} \quad$ Extract dosage of $200 \mathrm{mg} \mathrm{kg} \mathrm{day}^{-1}$

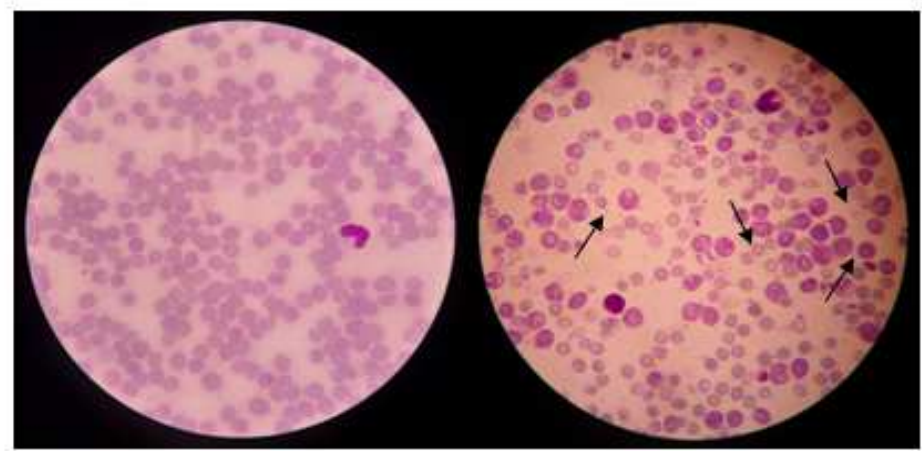

Positive control

Negative control

Fig. 1. Parasitemia density (thin blood smear) in combination test on the day 4, visualized using a light microscope (* arrow indicates parasite-infected erythrocytes) 
Parasitemia density in each treatment group is depicted in Fig. 1. The best parasite inhibitory activity was exhibited by control positive group and treatment group receiving $400 \mathrm{mg} \mathrm{kg} \mathrm{day}^{-1}$.

In the positive control group, recovery of the experimental animal began on the Day 3 and on the Day 4, all mice were found to be negative in parasitemia test.

Based on percent inhibition exhibited by each test group, statistic analysis was conducted to determine the significance in the different of percent inhibitions in the treatment groups receiving the extracts and the control group receiving chloroquine. Kruskal-Wallis statistic analysis exhibited a significance value of $\mathrm{p}=$ 0.021 . It means that at least three groups of mice had a significant difference in the percent inhibition $(\mathrm{p}<0.05)$.

\subsection{Acute Toxicity Test}

Acute toxicity tests were done for Xetospongia sp. Three groups of mice, eachgroup having 5 male and 5 female mice, for dose levels $(625,2500$ and $5000 \mathrm{mg}$ $\mathrm{kg}^{-1}$ ) were used for toxicity test. The mice were acclimatized and fasted over night. The weight of each mouse was measured and calculated for all the dose levels. The extracts were given to the mice before they ate anything (empty stomachs). The test was repeated with doses $\left(625,2500\right.$ and $\left.5000 \mathrm{mg} \mathrm{kg}^{-1}\right)$ orally. Toxicity signs such as death, changes in physical appearance, behavioral change and organ damage were observed for $48 \mathrm{~h}$.

The table above shows that up to a dosage of 5000 $\mathrm{mg} \mathrm{kg} \mathrm{day}{ }^{-1}$, extracts of Xetospongia sp administered for $48 \mathrm{~h}$ did not lead to mouse death, with an $\mathrm{LD}_{50}$ value of $>5000 \mathrm{mg} \mathrm{kg}^{-1}$.

\section{DISCUSSION}

Marine sponges have a potential to provide future drugs against important diseases, such as malaria, cancer and a range of viral diseases (Bhimba et al., 2013). Of 10,000 marine sponges, 11 genera are known to produce bioactive compounds and only three genera (Haliclona, Petrosia and Discodemia) are known to produce anti-malarial. Xetospongia sp is one of the sponges of genus Petrosia that are widely found in Indonesian water areas. Xetospongia is a genus of sponge that contains manzamine compound. Manzamines are a structurally unique group of bcarboline alkaloids isolated from a Halliclona sp but subsequently found in other genera of marine sponges including Xetospongia (Guzman et al., 2011). Ang et al. (2000) isolated manzamine-A, a, $\beta$ carboline alkaloid in several marine sponges, inhibiting the growth of the rodent malaria parasite Plasmodiumberghei in vivo. They also suggested the manzamine- $A$ and 8hydroxymanzamine-A, as promising new antimalarial agents/technical status of different methods to produce sponge.

The $P$. berghei-infected mouse model has been widely used as a preliminary test for the in vivo activity of potential antimalarial agents, as it provides a preclinical indication of any in vivo potential bioactivity as well as possible toxicity of the sample tested.

\subsection{Evaluation of Suppressive Activity of the Extract ( 4-Day Test)}

The 4-day suppressive test is a standard test commonly used for antimalarial screening and the determination of percent suppression of parasitemia is the most reliable parameter (Gitua et al., 2012). Evaluation of antimalaria activity was based on \%parasitemia 4 days after the test animals were given antimalaria treatment for 4 consecutive days. Plasmodium berghei is widely used for in vivo antiplasmodial activity assay since it is molecularly analogous to P. falciparum. By using P. berghei as a test Plasmodium, the research findings expectedly described the effects against $P$. falciparum as a Plasmodium that most commonly infects human being (Cox, 1988).

Malaria parasite infected mice exhibited the symptoms of trembling, anemia, paleness, weakness and reduced body weight. The mice looked pale due to anemia. The symptoms of anemia occurred since many erythrocytes were lysed due to parasite infection. Consequently, the counts of erythrocytes decreased. Reduced erythrocyte counts were evident from the fact that the mice blood was more diluted and pale. The mice also lost appetite for food. This led to decreasing body weight and weakness. The symptoms were similar to what human beings experience in case of malaria parasite infection. The 
development of malaria is also determined by the immune system of the test animals and their response to the treatment.

Table 1 shows that administration of Xetospongia sp extract at a dosage of $200 \mathrm{mg} \mathrm{kg} \mathrm{day}^{-1}$ was able to suppress parasite growth by $42,48 \%$, while a dosage of $400 \mathrm{mg} \mathrm{kg} \mathrm{day}{ }^{-1}$ was able to suppress parasite growth by $60,23 \%$. Therefore, the total $\mathrm{ED}_{50}$ value for the extract of Xetospongia sp administered on oral route was $331,95 \mathrm{mg} \mathrm{kg}^{-1}$.

\subsection{Evaluation of Curative Activity (Rane's test)}

In the curative study, the ethanolic extract of Xetospongia sp produced a dose dependent reduction in parasitaemia levels in the extract treated groups; there was also a similar reduction in the chloroquine treated group (positive control). This finding is sufficient to say that Xetospongia sp extract has therapeutic efficacy against established malaria parasite.

The extract produced significant $(\mathrm{p} \leq 0.05)$ and dose- dependent decrease in parasite counts. The mean percentage of parasitaemia were 8,52, 9,49, 6,02 and 4,17 at the doses of 50,100, 200 and $400 \mathrm{mg}$ extract $/ \mathrm{kg}$ body weight respectively Table 2 . At $10 \mathrm{mg}$ $\mathrm{kg}^{-1}$, Chloroquine produced $98.42 \%$ chemo suppression. The extract produced significant $(\mathrm{p}<0.05)$ dose-dependently prolonged the survival time of mice while, chloroquine at $10 \mathrm{mg} \mathrm{kg}^{-1}$ body weight significantly $(\mathrm{p}<0.001)$ prolonged the survival time of treated mice.

\subsection{Acute Toxicity Test}

In general, if the Lethal Dose (LD50) of the test substance is three times more than the Minimum Effective Dose (MED), the substance is considered a good candidate for further studies. It was also suggested that oral administration is about 100 times less toxic than intraperitoneal (Prohp and Onoagbe, 2012). However, the hydro alcoholic extracts showed no lethality to mice at $5,000 \mathrm{mg} \mathrm{kg}$, which is 25 times the MED and no gross behavioral and physical changes were revealed (Table 3). Therefore, observations that no death with up to an oral dose of $5000 \mathrm{mg} \mathrm{kg}{ }^{-1}$ could indicate that the test extracts are very safe.

Table 1. Effect of ethanolic extract of Xetospongia sp on suppressive activity

\begin{tabular}{|c|c|c|}
\hline Extract/drug & Percentage of parasitemia & Percentage of suppressive \\
\hline \multicolumn{3}{|l|}{ Xetospongia sp } \\
\hline 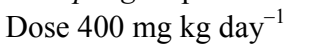 & $3,07 \pm 0,98$ & 60,23 \\
\hline $200 \mathrm{mg} \mathrm{kg} \mathrm{day}^{-1}$ & $4,44 \pm 0,87$ & 42,48 \\
\hline $100 \mathrm{mg} \mathrm{kg} \mathrm{day}^{-1}$ & $5,72 \pm 0,96$ & 25,91 \\
\hline 50 mg kg day ${ }^{-1}$ & $6,65 \pm 0,94$ & 3,86 \\
\hline Vehicle & $7,72 \pm 0,84$ & 0 \\
\hline Chloroquine $10 \mathrm{mg} \mathrm{kg}^{-1}$ & $0,13 \pm 0,97$ & 98,32 \\
\hline
\end{tabular}

Each results is mean of mice \pm controls

Table 2. Antiplasmodial activity of the ethanol extract of Xetospongia sp. during established infection (Rane test)

\begin{tabular}{lll}
\hline Extract/drug Xetospongia sp & Percentage of parasitemia & Mean survival time (day) \\
\hline Dose $400 \mathrm{mg} \mathrm{kg} \mathrm{day}^{-1}$ & $4,17 \pm 1,27$ & $16,52 \pm 1,03^{*}$ \\
$200 \mathrm{mg} \mathrm{kg} \mathrm{day}^{-1}$ & $6,02 \pm 1,13$ & $14,63 \pm 1,53^{*}$ \\
$100 \mathrm{mg} \mathrm{kg} \mathrm{day}^{-1}$ & $9,49 \pm 1,21$ & $10,42 \pm 1,42^{*}$ \\
$50 \mathrm{mg} \mathrm{kg} \mathrm{day}^{-1}$ & $8,52 \pm 0,98$ & $5,42 \pm 1,03$ \\
${\text { Chloroquine } 10 \mathrm{mg} \mathrm{kg}^{-1}}^{\text {Da }}$ & $0,00 \pm 0,09$ & $30,0 \pm 0,00^{*}$ \\
\hline
\end{tabular}

Data are expressed as mean \pm SEM for five mice/group $\square{ }^{*} \mathrm{p}<0,05$. When compared to control

Table 3. Physical changes of the ethanol extract of Xetospongia sp during acute toxicity test

\begin{tabular}{llll}
\hline Extract of Xetospongia sp & $12 \mathrm{~h}$ later & $24 \mathrm{~h}$ later & $48 \mathrm{~h}$ later \\
\hline Dose $625 \mathrm{mg} \mathrm{kg}^{-1}$ & No change behavior salivation & No change behavior & No change behaviour \\
$2500 \mathrm{mg} \mathrm{kg}^{-1}$ & No change behavior salivation & No change behavior & No change behaviour \\
$5000 \mathrm{mg} \mathrm{kg}^{-1}$ & Piloerection Rapid respiration salivation & No change behavior & No change behaviour \\
\hline
\end{tabular}




\section{CONCLUSION}

The ethanolic extract of Xetospongia sp produced a dose dependent reduction in parasitaemia levels in the extract treated groups; there was also a similar reduction in the chloroquine treated group (positive control). This finding is sufficient to say that Xetospongia sp extract has therapeutic efficacy against established malaria parasite. Acute toxicity of extract of Xetospongia sp observations that no death with up to an oral dose of $5000 \mathrm{mg} \mathrm{kg}^{-1}$ could indicate that the test extracts are very safe.

\section{ACKNOWLEDGEMENT}

This research was funded by Endowment B, IIUM (EDW B12-396-0874) and IIUM is gratefully acknowledged. We thank Farid Kamal Muzaki, the Laboratorium of Ecology of Marine, Department of Biology for collecting the sponges from Tanjung Pecoran, Situbondo and Dr Hashidah Mohd Sidek, Centre of Bioscience and Biotechnology, Faculty of Sciences and Technology, National University of Malaysia for providing the strain of $P$ berghei.

\section{REFERENCES}

Abdillah, S., A.P.D. Nurhayati, S. Nurhartika, E. Setiawan and W.L. Heffen, 2013. Cytotoxic and antioxidant activities of marine sponge diversity at Pecaron Bay Pasir Putih Situbondo East Java, Indonesia. J. Pharm. Res., 6: 685-689.

Ang, K.K.H., M.J. Holmes, T. Higa, M.T. Hamann and U.A.K. Kara, 2000. In vivo antimalarial activity of the beta-carboline alkaloid manzamine a. Agents Chemother, 44: 1645-1649. DOI: 10.1128/AAC.44.6.1645-1649.2000

Bhimba, V., V. Vinod and C. Beulah, 2013. Marine sponge Sigmadocia pumila a potential supply for drug findings. J. Pharm. Res., 6: 401-403. DOI: 10.1016/j.jopr.2013.04.006

Cox, F.E.G., 1988. Major Animal Models in Malarial Research: Rodent. In: Malaria: Principles and Practice of Malariology, Wernsdorfer, W.H. and I. McGregor (Eds.), Churchill Livingstone, Edinburgh, ISBN-10: 0443024170, pp: 1503-1543.

Davis, R.A., M.S. Buchanan, S. Duffy, V.M. Avery and S.A. Charman et al., 2012. Antimalarial activity of pyrroloiminoquinones from the Australian marine sponge Zyzzya sp. J. Med. Chem., 55: 5851-5858. DOI: $10.1021 / \mathrm{jm} 3002795$
Farokhi, F., P. Grellier, M. Clement, C. Roussakis and P.M. Loiseau et al., 2013. antimalarial activity of axidjiferosides, new $\beta$-galactosylceramides from the african sponge Axinyssa djiferi. Mar. Drugs, 11: 1304-1315. DOI: $10.3390 /$ md11041304

Gitua, J.N., D.R. Muchiri, X.A. Nguyen, 2012. In vivo antimalarial activity of ajuga remota water extracts against plasmodium berghei in mice. Southeast Asian J. Trop. Med. Public Health, 43: 545-8. PMID: 23077832

Guzman, E.A., J.D. Johnson, P.A. Linley, S.A Gunasekera and A.E. Wright, 2011. A novel activity from an old compound: Manzamine A reduces the metastatic potential of AsPC-1 pancreatic cancer cells and sensitizes them to TRAIL-induced apoptosis. Invest. New Drugs, 29: 777-785. DOI: 10.1007/s10637-010-9422-6

Knight, D.J. and W. Peters, 1980. The antimalaria activity of n-benzyloxydihydrotriazines. I. The Activity of Clociguanil (BRL 50216) against Rodent Malaria and Studies on its Mode of Action". Ann. Trop. Med. Parasitol., 74: 393-404. PMID: 7006531

Prohp, T.P and I.O. Onogbe, 2012. Acute toxicity and dose response studies of aqueous and ethanol extracts of Triplochiton scleroxylon K. Schum (Sterculiaceae). Int. J. Applied Biol. Pharm. Technol., 3: 400-409.

Ryley, J.F. and W. Peters, 1970. The antimalarial activity of some quinolone esters. Ann. Trop. Med. Parasitol., 84: 209-222. PMID: 4992592

Samoylenko, V., S.I. Khan, M.R. Jacob, B.L. Tekwani and L.A. Walker et al., 2009. Bioactive (+)manzamine A and (+)-8-hydroxymanzamine A tertiary bases and salts from Acanthostrongylophora ingens and their preparations. Nat. Prod. Commun., 4: 185-192. PMID: 19370920

SEARO, 2011. Malaria situation in SEAR Countries: Indonesia.

Sibley, C.H. and R.N. Price, 2012. Monitoring antimalarial drug resistance: Applying lessons learned from the past in a fast-moving present. Int. J. Parasitol: Drugs Drug Resistance, 2: 126-133. DOI: 10.1016/j.ijpddr.2012.03.004 